\section{US-Soviet space cooperation}

\section{Washington}

For cooperation in space as for arms control, the Moscow summit meeting last week between President Ronald Reagan and General Secretary Mikhail Gorbachev yielded modest, positive results, but no real breakthroughs. As expected, the meeting's joint communique included an agreement to expand civil space cooperation between the two countries. But the US delegation did not take up Gorbachev's explicit proposal (announced to the US press before the summit) of a joint Mars mission.

The most tangible item in the summit agreements will be the "exchange of flight opportunities". Scientific instruments from each country will fly on the other nation's space missions. The communique does not name specific collaborations, but several are already tentatively scheduled. In the first of such arrangements, NASA (National Aeronautics and Space Administration) plans to send a US-built ozone mapping instrument on the 1990 launch of a Soviet Meteor weather satellite. The instrument would be a slightly modified version of the Total Ozone Mapping Spectrometer (TOMS) that has been returning data about the deterioration of the ozone layer from the US Nimbus 7 spacecraft.

The Soviets, in turn, plan to include a receiver aboard the US Mars Observer spacecraft to be launched in 1992 . The Soviet instrument would relay images to Earth from a Soviet Mars balloon flight in 1994. Also on the docket are plans to launch an X-ray telescope developed by the United States and Denmark on a Soviet satellite in the mid-1990s. Some dozen or more similar exchanges are also reported to be under consideration.

The Soviet and US delegations also committed themselves to expanded exchanges of space data and scientists, but there was no movement on a joint Mars mission. Gorbachev had formally proposed a joint venture only days before the summit, a prospect which, according to some sources, sent the White House into a panic. The current US administration has consistently opposed the idea, and the Pentagon has expressed concern that such a collaboration would allow the Soviets to gain access to sensitive US technology.

A State Department spokesperson in Washington acknowledged that the summit resulted in only "a modest expansion" of previous goals on cooperative space ventures outlined in an April 1987 agreement between the two countries. Officials at NASA and the State Department stressed that it did, however, represent a small step forward. Seth Shulman

\title{
Out of the woods for Viennese molecular biology?
}

\section{Vienna}

Aвоuт fifty student demonstrators were on hand to mark the official opening at the end of May of a laboratory that is set to act as a focus for modern biological research in Vienna. The protesters, mainly students of Vienna University opposed to "gene and reproduction technology", were particularly exercised by the fact that the new Research Institute of Molecular Pathology (IMP) is a joint venture of two commercial concerns. But by 1991, the

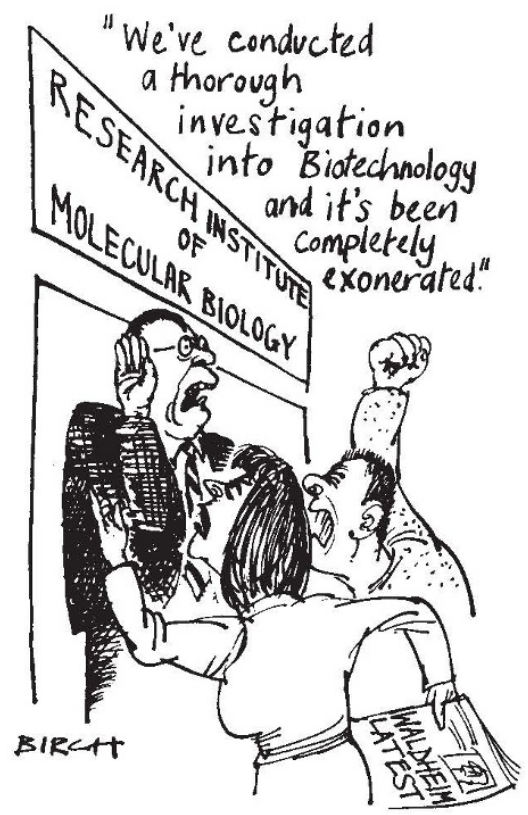

university hopes to have several institutes on the same site, creating a 'Biozentrum'.

Genentech, the Californian biotechnology company with aspirations to be a pharmaceutical company, and Boehringer Ingelheim, the West German pharmaceutical giant with which Genentech has had increasing links over the past few years, own and finance IMP, although the city of Vienna has contributed 20 per cent of the 700 million schillings ( $£ 35$ million) for the first five years.

Although the ultimate purpose of IMP is to produce product ideas for the two companies in the area of cancer therapy, the institute's brief is to carry out basic research. The companies believe IMP is the first basic research institute to be set up as a joint industrial venture.

The institute, with a total of 80 staff, is directed by Professor Max Birnstiel and has a scientific advisory board that includes Dr David Baltimore, director of the Whitehead Institute in Cambridge, Massachusetts. Five senior scientists have now been recruited within Europe and will all be in post by the end of the year.

Among the attractions for new staff are high salaries, generous transferable pen- sions and the provision of a service department for protein and DNA sequencing and synthesis. Senior appointments are for two years plus three years rolling tenure, a system Birnstiel would like to see spread in Europe. While IMP has an initial 12-year life-span, it can be considered as "permanent", says Clifford Orent, Genentech's director of international operations. Permanency, however, is likely to depend on the successful emergence of product ideas. Birnstiel hopes that these will emerge largely because his staff are conscious of the need and because of personal contacts with company scientists that he will strongly encourage.

Despite the demonstration by students, whose concerns were of the general kind that has emerged with some force in neighbouring West Germany, the activities of IMP seem unlikely to be affected. The students' concerns, however, may yet have some political impact.

While Professor Hans Tuppy, rector of Vienna University until last year when he became Austria's Minister of Science and Research, was one of the speakers at the institute's opening, other senior politicians were noticeable by their absence. Plausible excuses were available, but the suspicion remained in some quarters that genetic manipulation may be set to become a public issue in Austria and that some politicians wanted to keep their distance for that reason. Peter Newmark

\section{Californian centre for excellence named} Berkeley

A JoINT venture between Stanford University and the University of California's Berkeley and Santa Barbara campuses has been selected as one of five 'centers for excellence' to be funded by Sematech, the semiconductor manufacturing research consortium formed to try to restore US leadership in semiconductor manufacturing technology.

The other centres named are the University of Arizona for contamination and defect control, a group of New Jersey universities for plasma etching, the University of New Mexico for metrology and the Massachusetts Microelectronics Center for single-wafer processing. Each centre will receive between $\$ 500,000$ and $\$ 1.5$ million per year from Sematech for five years.

Sematech says the purpose of the centres is "to provide a focus for development of manufacturing programs within graduate schools of US universities".

Marcia Barinaga 